\title{
Measurement and analysis of cooling (heat) performance of renewable energy technology projects based on ground source heat pump systems
}

\author{
Cuiqing Chang ${ }^{1}$ \\ ${ }^{1}$ School of Management, Tianjin University of Technology, Tianjin 300384, China
}

\begin{abstract}
The design, configuration and operation of the soil-source heat pump system in four actual projects are monitored, collected and investigated. Combined with various test parameters of the project, the energy efficiency of the ground source heat pump system was compared and measured, and detailed data analysis was conducted from the aspects of heat exchange of ground source heat pump system, heat efficiency coefficient of ground source heat pump system, performance of ground source heat pump unit and performance of soil source heat pump system. It provides a basis for the formulation of operation strategy of soil-source heat pump system in the future, so as to serve the sustainable development of energy saving technology of shallow soil-source heat pump system.
\end{abstract}

\section{Introduction}

In the past 30 years, ground source heat pump system as a representative of renewable energy technology has been concerned by the industry. Compared with conventional air-conditioning systems, the ground source heat pump air-conditioning system is superior in energy efficiency, carbon emission, economy and other aspects ${ }^{[1]}$. As an important way of renewable energy utilization, China's ground source heat pump (especially buried pipe ground source heat pump) industry is developing rapidly ${ }^{[2]}$. Domestic scholars' researches on the performance of ground source heat pump system with buried pipes are mostly carried out based on short-term measured data and long-term simulated data ${ }^{[3,4]}$, while foreign researches are mostly carried out based on long-term monitoring data. Based on the above contents, this paper analyzes and evaluates the long-term measured data of four domestic practical applications, so as to provide data reference for the implementation and operation of similar projects in China in the future.

\section{Assessment project}

The information of the 4 items selected for testing in this paper is shown in Table 1.

According to GB 50366-2009 "technical specification for ground source heat pump systems engineering (hereinafter referred to as the"specification") test requirements, and USES the patent"an underground geotechnical thermal parameter detection system" (ZL201921496088.5) ${ }^{[5]}$ provide way of system testing for actual projects, according to load characteristics and the application characteristics of each project, carries on the scientific and rational system configuration design and project implementation. Among them,the design of soil source heat pump system of Nanjing ${ }^{[6]}, \mathrm{Xi}$ 'an and Weihai regional projects meets the annual heat absorption demand of the system, and the excess heat release is undertaken by the auxiliary cooling tower cooling system. Due to the influence of economic factors, although there is also a big difference between heat absorption and heat release, auxiliary heat dissipation equipment is not equipped in the implementation stage of the system, and only the cooling tower interface is reserved in the system. At the same time, the ground temperature monitoring device is added in the control system to track and record the temperature at the ground source side.

Table 1. Project data sheet.

\begin{tabular}{|c|c|c|c|c|}
\hline Project & Nanjing project & Xi 'an project & Weihai project & Beijing project \\
\hline Design cooling load $\mathrm{q}_{L} / \mathrm{kW}$ & 10750 & 4150 & 5010 & 5890 \\
\hline Design heat load $\mathrm{q}_{R} / \mathrm{k} W$ & 6440 & 3275 & 4610 & 5180 \\
\hline In cooling quantity $Q_{L} /(M W \cdot \mathrm{h})$ & 6234433 & 2349862 & 2105281 & 3170920 \\
\hline In heating load $Q_{R} /(M W \cdot \mathrm{h})$ & 3887712 & 2949180 & 2376965 & 2988774 \\
\hline
\end{tabular}

\footnotetext{
${ }^{*}$ Corresponding author: ccq19960612@stud.tjut.edu.cn
} 


\begin{tabular}{|c|c|c|c|c|}
\hline $\begin{array}{c}\text { Comprehensive thermal conductivity } \\
\text { of rock and soil mass } \lambda\end{array}$ & 1.96 & 2.15 & 3.13 & 5.68 \\
\hline $\begin{array}{c}\text { Original mean temperature of rock } \\
\text { and soil } T /{ }^{\circ} \mathrm{C}\end{array}$ & 16.35 & 19.65 & 13.79 & 15.69 \\
\hline
\end{tabular}

\section{Measuring index and method}

Generally, the energy efficiency of the heat pump unit and the operating energy efficiency of the buried pipe heat exchanger system should be tested to further calculate and analyze the energy saving, economic and environmental benefits of the soil-source heat pump system ${ }^{[7]}$. The test and evaluation indexes of the soil-source heat pump system are as follows.

a) Heat transfer energy efficiency coefficient of buried pipe. The heat transfer energy efficiency coefficient of the buried pipe represents the lowest or highest capacity of the outlet temperature of the fluid in the pipe after continuous heat transfer between the heat exchange pipe and the surrounding rock and soil mass. The test is divided into two parts: heat dissipation test and heat extraction test.

b) Performance of heat pump units. The performance of the heat pump unit refers to the performance of the unit under the actual operating conditions of the system, including the refrigerating efficiency ratio (EER) and the heating performance coefficient (COP). The calculation method is to divide the heat produced by the heat pump unit (cooling capacity) by the power consumed.

c) Performance of soil-source heat pump system. Soil- source heat pump system performance does not refer to the performance of a certain equipment, but refers to the overall performance of the whole system including all equipment, including refrigeration energy efficiency ratio $\left(E E R_{\text {sys }}\right)$ and system heating performance coefficient $\left(C O P_{\text {sys }}\right)$.

\section{Measured heat exchange of buried pipe}

\subsection{Heat loss test analysis}

The heat dissipation test is to simulate the operating conditions in summer and to calculate the actual heat dissipation of circulating water. During the normal operation of the four project systems, monitoring and recording of the water supply and return temperature data under the heat dissipation condition of the heat exchanger were conducted in this paper. Combined with the flow recorded at the source side of each project system, the heat dissipation of the single-hole heat exchanger of each project was calculated theoretically. The data obtained were shown in Table 2.

Table 2. Measured data of heat exchange of single hole heat exchanger.

\begin{tabular}{|c|c|c|c|c|c|}
\hline \multicolumn{2}{|c|}{ Parameter } & Nanjing project & $\mathrm{Xi}$ 'an project & Weihai project & Beijing project \\
\hline \multicolumn{2}{|c|}{ The parameters of the buried pipes } & $\begin{array}{l}1212 \text { holes, } \\
\text { effective depth }\end{array}$ & $\begin{array}{c}\text { 966hole, } \\
\text { effective depth }\end{array}$ & $\begin{array}{c}1 \text { 040hole, } \\
\text { effective depth }\end{array}$ & $\begin{array}{c}\text { 697hole, } \\
\text { effective depth }\end{array}$ \\
\hline \multirow{4}{*}{$\begin{array}{l}\text { The cooling } \\
\text { conditions }\end{array}$} & $\begin{array}{l}\text { Mean fluid inlet } \\
\text { temperature } /{ }^{\circ} \mathrm{C}\end{array}$ & 30.59 & 31.32 & 30.10 & 29.28 \\
\hline & $\begin{array}{c}\text { Mean fluid outlet } \\
\text { temperature/ }{ }^{\circ} \mathrm{C}\end{array}$ & 26.76 & 28.94 & 26.80 & 24.20 \\
\hline & $\begin{array}{l}\text { The average flow rate/ } \\
\left(\mathrm{m}^{3} \cdot \mathrm{h}^{-1}\right)\end{array}$ & 1.51 & 1.61 & 1.70 & 1.77 \\
\hline & $\begin{array}{l}\text { Yanmi dissipates heat/ } \\
\left(W \cdot \mathrm{m}^{-1}\right)\end{array}$ & 55.91 & 44.38 & 59.39 & 86.91 \\
\hline \multirow{4}{*}{$\begin{array}{l}\text { Working } \\
\text { condition of } \\
\text { heat removal }\end{array}$} & $\begin{array}{l}\text { Mean fluid inlet } \\
\text { temperature } /{ }^{\circ} \mathrm{C}\end{array}$ & 8.05 & 6.57 & 6.30 & 7.52 \\
\hline & $\begin{array}{l}\text { Mean fluid outlet } \\
\text { temperature } /{ }^{\circ} \mathrm{C}\end{array}$ & 10.96 & 9.03 & 9.10 & 11.27 \\
\hline & $\begin{array}{l}\text { The average flow rate/ } \\
\left(\mathrm{m}^{3} \cdot \mathrm{h}^{-1}\right)\end{array}$ & 1.56 & 1.29 & 1.36 & 1.53 \\
\hline & $\begin{array}{l}\text { The heat is taken from } \\
\text { the kilometer } /\left(W \cdot \mathrm{m}^{-1}\right)\end{array}$ & 43.86 & 37.01 & 40.12 & 55.49 \\
\hline
\end{tabular}

\subsection{Thermal analysis}

The heat extraction test is to simulate the operating conditions in winter. The soil-source heat pump takes the underground soil as the heat source, obtains heat from the underground soil layer through the buried pipe heat exchanger, and then transfers it to the heat pump system. In this paper, four project systems are selected to monitor and record and sort out the data of water supply and return temperature under the heat exchanger taking condition during normal operation. The data obtained are shown in Table 2. 


\subsection{Compared with theoretical values}

According to the characteristics analysis and the calculation of the EED program developed by the Gfunctions algorithm recommended in the Specification, the statistics of heat exchange for theoretical single elongmeter are shown in Table 3.

Table 3. Heat excha theoretical single length meter heat transfer data table. Units: $\mathrm{W} / \mathrm{m}$

\begin{tabular}{|c|c|c|c|c|}
\hline Project & $\begin{array}{c}\text { Nanjing } \\
\text { project }\end{array}$ & $\begin{array}{c}\mathrm{Xi} \text { 'an } \\
\text { project }\end{array}$ & $\begin{array}{c}\text { Weihai } \\
\text { project }\end{array}$ & $\begin{array}{c}\text { Beijing } \\
\text { project }\end{array}$ \\
\hline $\begin{array}{c}\text { The heat is } \\
\text { scattered } \\
\text { from the } \\
\text { kilometer }\end{array}$ & 53.98 & 42.63 & 57.40 & 83.94 \\
\hline $\begin{array}{c}\text { The heat is } \\
\text { taken from } \\
\text { the } \\
\text { kilometer }\end{array}$ & 41.28 & 35.92 & 39.59 & 58.82 \\
\hline
\end{tabular}

The measured value of heat dissipation of the buried pipe heat exchanger per meter of the 4 projects analyzed in this paper is slightly higher than the theoretical value. The measured value of heat dissipation in the 4 projects tested is respectively $3.45 \%, 3.94 \%, 3.34 \%$ and $3.41 \%$. In addition to the Beijing project, the measured value of heat absorption of buried tube heat exchanger per length meter was also slightly higher than the theoretical value, and the measured value of heat absorption in the tested project was $5.88 \%, 2.95 \%$ and $1.33 \%$, respectively.

To sum up, through the analysis of the data of 4 actual projects in different regions, the special calculation software recommended in the Specification is used to calculate the design of buried pipe heat exchanger. The data is reasonable and can be applied to the design of large projects in different regions more accurately.

\section{Performance evaluation of project systems in different areas}

\subsection{Evaluation of heat exchange efficiency coefficient of buried pipe}

Based on the traditional concept of heat exchanger energy efficiency, a single U-shaped heat exchanger energy efficiency coefficient $\mathrm{E}$ is defined as the ratio of the actual heat exchange $\mathrm{Q}$ to the maximum theoretical heat exchange Q'. For the pipelines with multiple buried pipes, the comprehensive heat exchange energy efficiency coefficient $E_{Z}$ is used for evaluation, which is defined as the ratio between the average value of actual heat exchange $\mathrm{Q}$ of the buried pipes and the theoretical maximum heat exchange $\mathrm{Q}^{\prime}$, which is a dimensionless quantity, namely:

$$
E_{Z}=\frac{\frac{1}{\mathrm{n}} \sum_{\mathrm{i}=1}^{\mathrm{n}} Q}{Q^{\prime}},
$$

In Equation (1), $\mathrm{n}$ is the number of $\mathrm{u}$-shaped tubes in the tube group.

\subsection{Performance evaluation of ground source heat pump unit}

According to the measured heat generation (cooling capacity) and power consumption of the ground source heat pump unit, the refrigerating energy efficiency ratio (heating performance coefficient) of the ground source heat pump unit at each moment during the test is calculated, as shown in Equation (2):

$$
E E R / C O P=N i^{Q i}
$$

In equation (2), $Q_{1}$ is the average cooling (heat) amount of the unit during the test period, $\mathrm{kW} ; N_{\mathrm{i}}$ Is the average input power of the unit during the test period, $\mathrm{kW}$.

The measured refrigerating energy efficiency ratio and heating performance coefficient of the heat pump unit shall comply with the provisions of the project design document. If there is no specific provision in the design document, it shall comply with the provisions of the relevant national design code. Table 4 shows the analysis data of the heat pump unit's heating performance coefficient in winter and refrigeration energy efficiency ratio in summer under the normal operation state of the ground source heat pump unit in the four projects in this paper.

Table 4. Heat pump unit performance table.

\begin{tabular}{|c|c|c|c|c|}
\hline $\begin{array}{c}\text { Working } \\
\text { condition }\end{array}$ & $\begin{array}{c}\text { Nanjing } \\
\text { project }\end{array}$ & $\begin{array}{c}\text { Xi 'an } \\
\text { project }\end{array}$ & $\begin{array}{c}\text { Weihai } \\
\text { project }\end{array}$ & $\begin{array}{c}\text { Beijing } \\
\text { project }\end{array}$ \\
\hline $\begin{array}{c}\text { Refrigeration } \\
\text { energy } \\
\text { efficiency ratio } \\
\text { (EER) }\end{array}$ & 4.99 & 4.93 & 5.47 & 6.09 \\
\hline $\begin{array}{c}\text { Coefficient of } \\
\text { heating } \\
\text { performance } \\
\text { (COP) }\end{array}$ & 4.31 & 4.14 & 4.67 & 4.47 \\
\hline
\end{tabular}

The heat pump units of each project have a thermal performance coefficient distribution between 4.1 and 4.7 in winter and a refrigeration ENERGY efficiency ratio distribution between 4.9 and 6.1 in summer, which all meet the requirement of performance coefficient $\geqslant 4.0$ in GB/T 19409-2013 "Water (Ground) Source Heat Pump Units".

\subsection{Performance evaluation of soil-source heat pump system}

According to the total temperature of water supply and return medium and system flow rate of the soil-source heat pump system during the test period, hourly refrigerating capacity or heating capacity of the system at different times is calculated, and the system power at each time is summed to obtain the accumulative input power of the system at different times, and then the performance coefficient of the system at different times is obtained. The specific formula is as follows:

$$
E E R_{\mathrm{sys}}=\frac{Q_{S C}}{\Sigma N_{\mathrm{i}}+\Sigma N_{\mathrm{j}}},
$$




$$
C O P_{\text {sys }}=\frac{Q_{S H}}{\Sigma N_{\mathrm{i}}+\Sigma N_{\mathrm{j}}},
$$

In Equations (3) to (4), $Q_{S C}$ is the accumulated cooling capacity during the system test period, $\mathrm{k} W \cdot \mathrm{h} \cdot Q_{S H}$ Is the accumulated heat produced during system testing, $\mathrm{k} W \cdot \mathrm{h}$; $\Sigma N_{\mathrm{i}}$ represents the cumulative power consumption of all heat pump units during the system test, $\mathrm{k} W \cdot \mathrm{h} ; \Sigma N_{\mathrm{j}}$ represents the cumulative power consumption of other equipment during the system test, $\mathrm{k} W \cdot \mathrm{h}$.

The refrigerating energy efficiency ratio and heating performance coefficient of the soil-source heat pump system shall comply with the provisions of the design document. If there are no specific provisions in the design document, the refrigerating energy efficiency ratio of the system shall be $\geqslant\left(E E R_{\text {sys }}\right) 3.0$ and the heating performance coefficient of the system shall be $\geqslant\left(C O P_{\text {sys }}\right)$ 2.6 .

Table 5 shows the calculation and statistics of system refrigeration energy efficiency ratio $\left(E E R_{\text {sys }}\right)$ and system heating performance coefficient $\left(C O P_{\text {sys }}\right)$ of the four regional projects in this paper under the normal operation state of GSHP units. All items meet the above limits.

Table 5. Table of refrigerating energy efficiency ratio and heating performance coefficient of different project system.

\begin{tabular}{|c|c|c|c|c|}
\hline Project & $\begin{array}{c}\text { Nanjing } \\
\text { project }\end{array}$ & $\begin{array}{c}\text { Xi 'an } \\
\text { project }\end{array}$ & $\begin{array}{c}\text { Weihai } \\
\text { project }\end{array}$ & $\begin{array}{c}\text { Beijing } \\
\text { project }\end{array}$ \\
\hline$\left(E E R_{\text {sys }}\right)$ & 3.87 & 3.72 & 3.84 & 4.09 \\
\hline$\left(C O P_{\text {sys }}\right)$ & 3.43 & 3.22 & 3.40 & 3.25 \\
\hline
\end{tabular}

\subsection{Soil source heat pump system performance rating}

If the design value of refrigeration energy efficiency ratio and heating performance coefficient of the system is not less than the limit value, it is judged that the soil-source heat pump system has qualified performance, and the performance level can be evaluated. The performance of the soil-source heat pump system in cooling season and heating season should be rated respectively, and the lower grade should be selected. The performance levels of soilsource heat pump system are shown in Table 6.

Table 6. Performance levels of soil-source heat pump system are divided.

\begin{tabular}{|c|c|c|c|}
\hline $\begin{array}{c}\text { Working } \\
\text { condition }\end{array}$ & 1 level & 2level & 3 level \\
\hline $\begin{array}{c}\text { Working } \\
\text { condition of } \\
\text { refrigeration }\end{array}$ & $E E R_{\text {sys }} \geq 3$ & $\begin{array}{c}3.9> \\
E E R_{\text {sys }} \geq 3.4\end{array}$ & $\begin{array}{c}3.4> \\
E E R_{\text {sys }} \geq 3.0\end{array}$ \\
\hline $\begin{array}{c}\text { Heating } \\
\text { conditions }\end{array}$ & $C O P_{\text {sys }} \geq 3$ & $\begin{array}{c}3.5> \\
C O P_{\text {sys }} \geq 3.0\end{array}$ & $\begin{array}{c}3.0> \\
C O P_{\text {sys }} \geq 2.6\end{array}$ \\
\hline
\end{tabular}

In this paper, the four projects are divided into two levels of heating performance coefficient, two levels of refrigeration energy efficiency ratio, except for the Beijing project up to level 1, the other projects are all level 2, and the comprehensive evaluation level of soil-source heat pump system performance is up to level 2 standard.

\section{Conclusion}

In view of the actual test data of the project, respectively from the buried pipe heat exchanger, heat exchange coefficient of energy efficiency and performance of ground source heat pump units, such as soil source heat pump system performance for research and analysis, the following conclusion: a) the specification recommended use special calculation software for design and calculation of ground heat exchanger, the method is scientific and reasonable, can more accurately matching system operation scheme. B) After data analysis on the heat transfer performance of buried pipe in actual projects, it is found that the measured heat dissipation and heat absorption per kilometer of buried pipe heat exchanger in other projects are slightly higher than the theoretical value, and the design deviation value is no more than $\pm 6 \%$, except for the project in Beijing area, because the actual operation heat is lower than the design value. C) Due to the scientific and reasonable design method of buried pipe heat exchanger, the heat pump units of each project have a thermal performance coefficient distribution between 4.1 and 4.7 in winter and a refrigeration ENERGY efficiency ratio distribution between 4.9 and 6.1 in summer, which all meet the requirements of unit performance coefficient $\geqslant 4.0$. D) All projects meet the requirements of the limits of the refrigerating energy efficiency ratio and heating performance coefficient of the soil-source heat pump system, or even far exceed the limits; The performance grades of soil-source heat pump system are all up to level 2 or above, with remarkable energy saving effect.

\section{References}

1. Self S, Reddy B, Rosen M. Geothermal heat pump systems: status review and comparison with other heating options[J]. Applied energy, 2013,101(1):341348.

2. Wei Y, Jin Z, Wei X, et al. Current status of groundsource heat pumps in China[J]. Energy policy,2010, 38(1):323-332.

3. Liu Y, Qin P, Wang P. Experimental research and numerical simulation of buried pipe heat exchanger [J]. Refrigeration and Air Conditioning (Sichuan),2011(1):82-85.

4. Liu Y, Pang Y, Xu Y. Experimental study on heating characteristics of soil-source heat pump system in cold region [J]. Heilongjiang Science and Technology Information,2016(1):204-205.

5. Beijing Zhongchuang Green System Technology Co. LTD. An underground geotechnical thermal parameter detection system: ZL201921496088.5[P]. 2020-06-02. 
6. Zou M, Shen R, Chen F, et al. Methods and analysis of geotechnical thermophysical parameters for a project in Nanjing city [J]. Ground Source Heat Pump,2020(1-2):77-82.

7. Liu J, Lei Y, Yang M. Evaluation and analysis of application effect of ground source heat pump project of buried pipe in Beijing [J]. Resources and Industry,2017(2):80-85. 